\title{
Costs Comparison between FSC and Non FSC Acacia Plantations in Quang Tri Province, Vietnam
}

\author{
Hai Thi Nguyen Hoang, Satoshi Hoshino, and Shizuka Hashimoto
}

\begin{abstract}
Due to market demand, the FSC certification has been introduced and developed in Vietnam. Despite of many challenges, FSC certificate has been proved to bring economic benefits to the owners. The comparison to non-certified Acacia plantation shows that the management of certified forests does not increase the cost at high level, while the income of selling FSC wood logs is very promising. However, since currently the certification is subsidized and stumpage price is kept at higher than normal to foster the participation of local people the current price premium should be treated with caution. As for sustainable development, local people need to manage the certification by themselves which then, required them to have a good financial plan to cover the necessary fee. Further calculation need to be carried out in order to know how much membership fee can be collected in order to maintain the certification while do not affect to local people' revenue.
\end{abstract}

Index Terms-Forest certification, forest management, certification, Acacia plantations.

\section{INTRODUCTION}

The Forest Stewardship Council (FSC) arose from the realization that while many forest problems are intensifying, domestic and international governmental efforts and responses have been strongly criticized as inadequate and too slow for proper global forest management. As result of this, after a failure to attain agreement on a global forest convention in Rio Summit 1992, some of the world's leading environmental groups such as Swedish Society for Nature Conservation, Greenpeace and Stichting FERN, leading by World Wide Fund for Nature (WWF) decided to sidestep governments and in 1993 created the FSC. Their solution was relatively simple: develop a set of global principles and criteria of sustainable forestry, have national and subnational multi-stakeholder committees develop regionally appropriate standards, have third parties audit forestry operations for compliance, and "certify" those who pass the test - providing them with a badge of honor that, the hope was, would allow certified operations to gain some type of market advantage vis-à-vis their competitors (such as market access, price premiums, and the more abstract notion of a "social license to operate [1].

Vietnam is a Southeast Asia which recently has rapidly built a dynamic wood processing industry and in the last decade has earned reputation as a world-class producer of wooden furniture exporting 90 per cent of its total furniture production to 120 countries. In 2007, exports of furniture

Manuscripts received October 3, 2014; revised March 12, 2015.

Hai Thi Nguyen Hoang, Satoshi Hoshino, Shizuka Hashimoto are with Laboratory of Sustainable Developemt, Graduate School of Global Environmental Studies, Kyoto University, Japan (email: hai.htn@gmail.com,hoshino@kais.kyoto-u.ac.jp, hash@kais.kyoto-u.ac.jp). reached US\$ 2.4 billion in value, a stunning ten-fold increase since 2000, making wood products Vietnam's fifth largest export earner. However, since domestic timber production just supply $20 \%$ of the demand, Vietnam producers now depend heavily on imported material from Malaysia, Indonesia, Laos, etc. [2]. The dependence on imported materials makes Vietnam's wood processing firms vulnerable to the fluctuation in material supply. Moreover, the increasing concern from importing countries (Japan, USA, etc.) regarding legality and sustainability of forest production including work conditions of forest workers will also limit a furniture firms' choice of wood material suppliers in the future [3]. Thus, currently, the government of Vietnam is pushing the certification of plantation forest in Vietnam as a long term development strategy to foster the value of the timber production as well as domestic furniture industry. It is projected that $30 \%$ of its plantation forest area will be certified by a certain scheme by 2020 (equivalent to 2.4 million ha of forest [4].

\section{ACACIA TREe In Plantations IN VIETNAM}

Vietnam in 1943 had 14.3 million ha of forest; $42 \%$ of this area was destroyed in the period to 1995. Since the late 1980s, Vietnam has been implementing a major reforestation program (e.i. 5 million hectare reforestation program) with the main target to restore the forest area to 13.7 million ha by 2012 , remaining native forests had been protected, and tree plantations supply a thriving timbergrowing, processing and furniture-export industry, from that benefits poor smallholder farmers and rural communities [5]. Plantation development in Vietnam has focussed on monocultures of fast-growing exotic species of Eucalyptus, Acacia and Pinus [6]. This kind of trees with its capable of tolerating unfertilized soil and quick rotation are now being grown on rotations of less than 10 years and are providing relatively quick cash [7]. However, due to short rotation, most of wood from plantation is suitable for firewood and chip wood with low value. In order to increase the value of plantation forest's products, the certification by FSC seems to be one potential direction. As FSC with its detailed criteria requires the systematic management of the forest in terms of environment, economy and society, plantations in pursuing this certificate would produce wood logs, which bring much higher value compare to wood chip. In fact, in 2010, in Quang Tri province- Vietnam, the first harvest of timber with FSC logo has archived price higher than normal $25-30 \%$ imply the opportunity to increase value of Acacia plantation. However, the certification has just started recently and along with monetary benefits many problems need to be dealt with such as the low level forest expertise 
of local people, complex and high costs for certification, etc. [8]. This article analyses the economics aspects of certified plantation forest and make a comparison with non- certified forest. From this, we try to figure out challenges of people who want to maintain the certification as well as obstacles pushing people to abort the certification for their Acacia plantations.

\section{RESEARCH TARGET}

Quang Tri province is located in Central Vietnam (Fig. 1). About $48.9 \%$ of its natural land is forest or forestry land (Table I). In 2010, State Secretariat for Economic Affairs (SECO) and the World Wide Fund for Nature (WWF) implemented the project to certify plantation forest in Quang Tri. The project called for smallholder farmers to obtain Forest Steward Council (FSC), with the objectives to gain higher price for responsibly managed wood and to improve the income generation as well as livelihood of local people. By this project, the earliest FSC certification in Vietnam was given to group of smallholders. Group certification allows a group of forest owners to join together under a single FSC certificate and share certification costs among the group members. This has enabled forest owners to dramatically reduce the cost necessary for introducing FSC. The number of group member is not limited, but the group has to be managed effectively and function according to FSC rules. In the long term development strategy, the expansion of FSC certificate is aimed to supply the increasing demand of domestic (and international) companies of legally-sourced material wood which is now required when exporting to some sensitive market such as European countries or United State, where forest-related laws have been started, e.i. the Forest Law Enforcement, Governance and Trade/Voluntary Partnerships Agreement and The Lacey Act, respectively.

Currently the total forested area in Quang Tri is 231,653 ha, in which 861.8 ha has been certified under FSC. The local authority set 2020 target that 42,000 ha of plantation forest will be under FSC certificate (Table I).

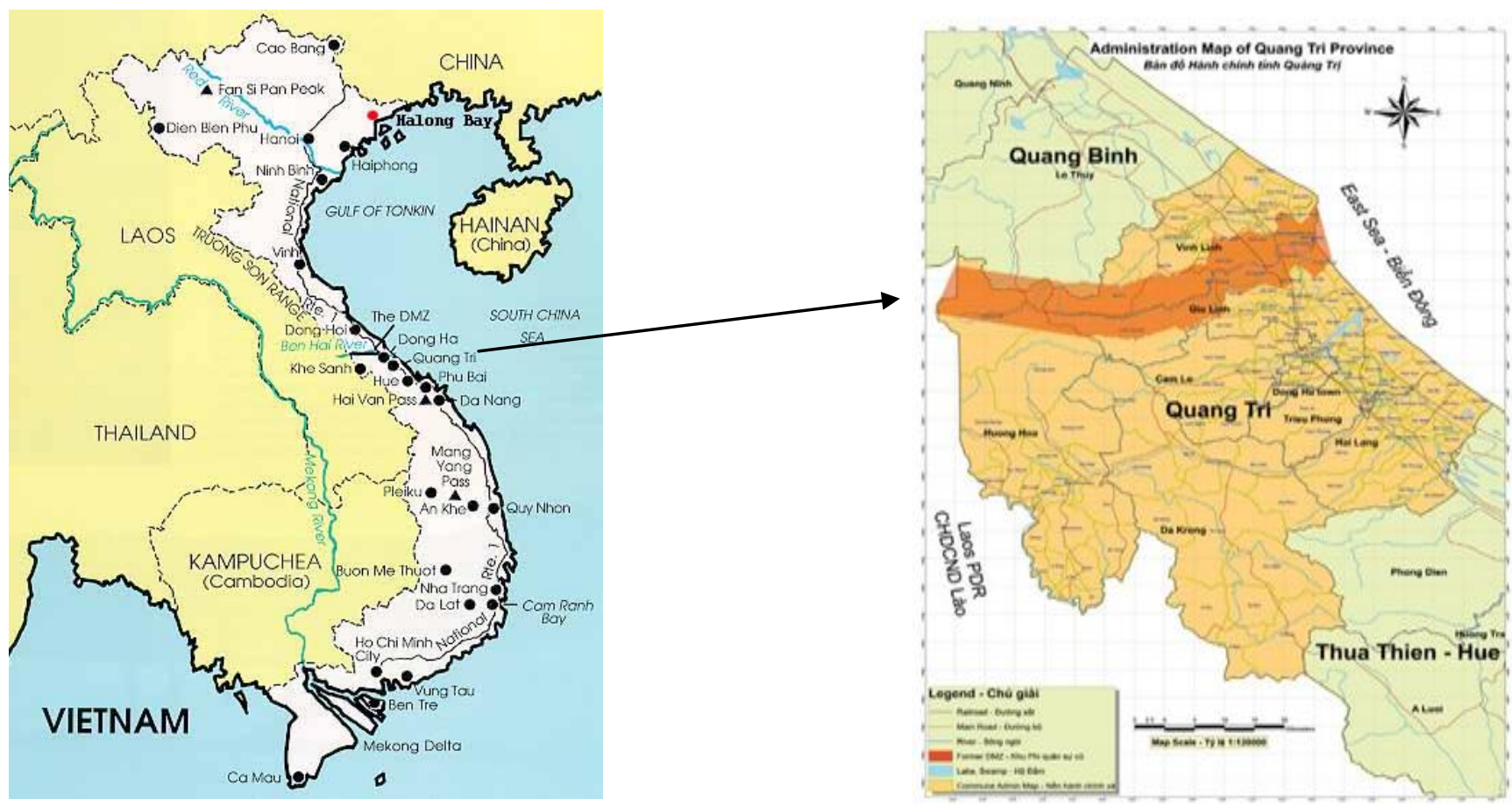

Fig. 1. Map of location of Quang Tri province in Vietnam.

TABLE I: SOME MAIN INFORMATION ABOUT QuANG TRI PROVINCE

\begin{tabular}{ll}
\multicolumn{2}{c}{ (PROVINCIAL DOF, 2013) } \\
\hline \hline Total land area & 473,981 ha \\
\hline Total forested area & 231,653 ha \\
Projected total forested area & 334.394 ha \\
Forest coverage: & $48.9 \%$ \\
Natural forest & 139,860 ha \\
Plantation forest & 91,792 \\
Total FSC certified area & 861.8 ha (as of July 2014) \\
Total population & 601.672 \\
& Urban: $28.31 \%$ \\
& Rural: $71.69 \%$ \\
GDP per capita & 620 USD (2010) \\
\hline \hline
\end{tabular}

\section{Methodology And Data Source}

Data were collected through face-to-face interviews conducted from August to September 2013 and May 2014 For the purpose of economic analysis, the content focused on clarify how much is paid for initial setup of a completely new Acacia plantation with density 1700-2000 trees, annual cost for forest maintenance and harvest cost (including debarking and transportation fee). Total 22 households responded to the survey. Though different households have different rotation length (varies from 6 to 14 years) the establishment cost is quite similar since they all follow the guidance which was provided long time ago. In order to determine the cost paid for taking care of the forest, we made use of the average data for the cost and revenue of Acacia plantations. The initial set up of FSC and non-FSC plantation is quite the same due to the fact that FSC is awarded to the already-existed- plantation. In order to make a comparison between forests with and without FSC 
certification, Net present value (NPV) is employed. It is one of the most commonly used measures of investment desirability of investment projects. Calculation formula is described as below:

$$
N P V=-C_{0}+\sum_{i=1}^{T} \frac{C_{i}}{(1+r)^{i}}
$$

Of which: $C_{0}$ : Initial investment, $\mathrm{C}$ : Cash flow; $r=$ discount rate, $i$ : period of time (year)In this article, we adopted an interest rate of $6 \% y^{-1}$ case analysis which is regarded as the long-term borrowing rate in the country. Simply understanding, NPV is an indicator of how much value an investment adds to the owner (if NPV $<0$ means the investment should be rejected).

\section{RESULTS}

The following Table II and Table III demonstrate costs for establishment and taking care of Acacia plantation for the period of 7 years. The cost is based on the average of household interview results. In fact, households maintain the forest in a wide range of rotation length (5 years, 7 years, 9 years and more) but in this calculation we take the typical rotation period of 7 years which is long enough to produce wood $\log$ with diameter that meet the FSC requirements.

\begin{tabular}{|c|c|c|c|c|c|c|c|c|c|}
\hline Number & Item & Total & 1 & 2 & 3 & 4 & 5 & 6 & 7 \\
\hline Yield & $117.5 \mathrm{~m} 3$ & & & & & & & & \\
\hline \multirow[t]{4}{*}{1} & Cash inflow & & & & & & & & \\
\hline & Timber selling & 7,100 & & & & & & & 7,100 \\
\hline & Pulpwood & 1,298 & & & & & & & 1,298 \\
\hline & Subtotal & 8,398 & & & & & & & 8,398 \\
\hline \multirow[t]{11}{*}{2} & Cash outflow & & & & & & & & \\
\hline & Site preparation & 60 & 60 & & & & & & \\
\hline & Seedlings & 38 & 38 & & & & & & \\
\hline & Fertilizer & 84 & 42 & 42 & & & & & \\
\hline & Planting cost & 70 & & & & & & & \\
\hline & Weeding/Tending & 100 & 50 & 25 & 25 & & & & \\
\hline & Protection & 70 & 10 & 10 & 10 & 10 & 10 & 10 & 10 \\
\hline & Charges for felling tree & 397 & & & & & & & 397 \\
\hline & Transportation fee & 300 & & & & & & & 300 \\
\hline & FSC cost & 60 & & & 20 & 10 & 10 & 10 & 10 \\
\hline & Subtotal & 1,179 & & & & & & & \\
\hline 3 & Net cash flow & 7,219 & & & & & & & \\
\hline 4 & NPV/ha & $4,776.82$ & & & & & & & \\
\hline \multicolumn{10}{|c|}{ TABLE III: COST STRUCTURE FOR NON-FSC ACACIA PLANTATION (7 YeAR ROTATION) } \\
\hline Number & Item & Total & 1 & 2 & 3 & 4 & 5 & 6 & 7 \\
\hline Yield & $117.5 \mathrm{~m} 3$ & & & & & & & & \\
\hline \multirow[t]{4}{*}{1} & Cash inflow & & & & & & & & \\
\hline & Timber selling & 4,365 & & & & & & & 4,365 \\
\hline & Pulpwood & 1,920 & & & & & & & 1,920 \\
\hline & Subtotal & 6,285 & & & & & & & 6,285 \\
\hline \multirow[t]{10}{*}{2} & Cash outflow & & & & & & & & \\
\hline & Site preparation & 60 & 60 & & & & & & \\
\hline & Seedlings & 38 & 38 & & & & & & \\
\hline & Fertilizer & 84 & 42 & 42 & & & & & \\
\hline & Planting cost & 70 & & & & & & & \\
\hline & Weeding/Tending & 100 & 50 & 25 & 25 & & & & \\
\hline & Protection & 70 & 10 & 10 & 10 & 10 & 10 & 10 & 10 \\
\hline & Charges for felling tree & 397 & & & & & & & 397 \\
\hline & Transportation fee & 552 & & & & & & & 300 \\
\hline & Subtotal & 1,371 & & & & & & & \\
\hline 3 & Net cash flow & 4,914 & & & & & & & \\
\hline 4 & NPV/ha & $3,400.65$ & & & & & & & \\
\hline
\end{tabular}

Our analysis clarified that, in term of economic expense, there is no big difference in taking care of forest for FSC certification or no purpose of certification (Fig. 2). Perhaps it was due to the fact that certification cost is covered by the donor and the certification has just started recently (from 2009) thus establishment costs between certified and noncertified is almost the same. However, transportation fee for non-FSC planation costs more than the other one due to the fact that most non-FSC plantation produce chip wood (not round wood $\log$ ). Anyway, the analysis of monetary benefits of FSC is still worth to be considered since it can reveal the main reasons that make the revenue of FSC plantation higher which includes: i.e. higher selling price and lower transportation cost. In our calculation, FSC certification cost is estimated at US\$ 60 (Table II), which is based on the number of working days people have to spend for the FSCrelated work. This estimation is higher compared to the level of US\$ 22-31 per ha which Tuan, 2013 provided in a project report to WWF-Vietnam. Nevertheless, the certification cost just a small portion in the total cost while revenue premium earned by FSC plantation owners is about 1.4 times of that of non-certified plantations (in term of NPV value per ha US\$ 4,776.82 versus US\$ 3,400.65). The harvest value from plantation with no FSC certificate is US\$ 6,285 (Table III) 
while with FSC certificate, the value is increased to US\$8.398 (Table II). It seems obvious that FSC certificate would bring higher income for local people, and therefore, more and more people are attracted to join the group. However, one remarkable fact is, still there were 20 households withdraw from the group certification in 2012 (Table IV). Interviews with these 20 households have been carried out in order to understand reasons they withdraw from the group.

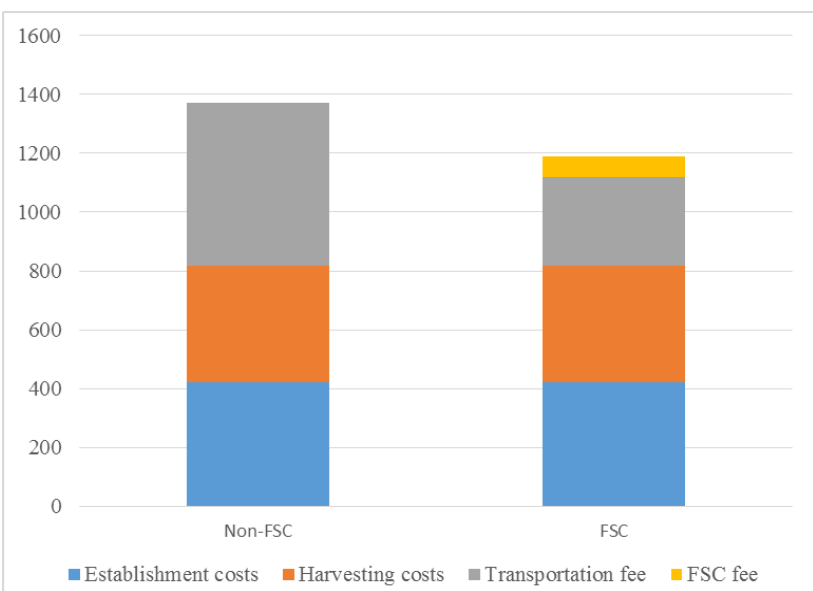

Fig. 2. Comparison of cost structure of Acacia timber production for FSC and non FSC plantation.

TABLE IV: NUMBER OF THE GROUP'S MEMBERS IN 2012 AND 2013

\begin{tabular}{|c|c|c|c|c|c|}
\hline 2012 & & 2013 & \multicolumn{3}{|c|}{ Difference } \\
\hline Area ( & N\#O & Area & $\mathrm{N \# O}$ & Area (ha) & N\#of hhs \\
\hline \multirow[t]{2}{*}{571.8} & 231 & 861.8 & 334 & 290 & 103 \\
\hline & & & & \multicolumn{2}{|c|}{$\begin{array}{l}123 \text { new members } \\
20 \text { households withdrew }\end{array}$} \\
\hline
\end{tabular}

TABLE V: POPULAR REASONS EXPLAINING THE WITHDRAWAL FROM THE FSC GROUP (INTERVIEW RESULTS, $N=20$ )

\begin{tabular}{lcc}
\hline \hline Reasons & $\begin{array}{l}\text { Number } \\
\text { mentioned/Percentage }(\mathbf{N = 2 0})\end{array}$ \\
\hline $\begin{array}{l}\text { Don't see the benefits of FSC } \\
\text { yet }\end{array}$ & $9(45 \%)$ \\
$\begin{array}{l}\text { Daunting paper work when } \\
\text { want to sell the tree }\end{array}$ & $15(75 \%)$ \\
$\begin{array}{l}\text { Lack of money } \\
\text { Fear of disaster* }\end{array}$ & $20(100 \%)$ \\
\hline \hline
\end{tabular}

*(Table VI)

All people mention the lack of money when they quit the group (Table V). It is quite understandable since they have no preparation (in financial aspect, such as savings) in order to extend the rotation length of their Acacia forest. In addition, they also doubt the possibility of price premium for FSC wood. "None of my neighbour sell the FSC wood, I'm don't know whether I can sell the trees at higher price or not, what if the project finishes". Besides, many people are $(75 \%)$ afraid of all paper work in order to maintain the certificate. In traditional way of selling Acacia tree, owner and merchant discussed and agreed on selling price then merchant would be in charge of all the necessary work for harvesting including tree felling, transportation to wood processing enterprise. However, selling FSC certified Acacia plantation requires the classification wood log based on its diameter, and moreover, counting number of wood logs in each category, labelling the FSC logo and keep record. These tasks consume time and efforts therefore, are considered troublesome for people at low level of forestry expertise. Besides, $35 \%$ of the respondents express the fear that disaster can destroy their forest if they don't sell when the tree are at merchant age (4-5 years) and have to lengthen the rotation until 7 years or more. At the local research site, forest fire is considered the biggest risk to the forests since it can lead to tremendous loss, typhoon is ranked the second, and the third one is pests and diseases on Acacia trees (Table VI).

TABLE VI: Risks EVALUATION By LOCAL PEOPLE (INTERVIEWS RESULTS,

\begin{tabular}{|l|l|}
\hline \multicolumn{2}{|c|}{$N=7)$} \\
\hline Type of risk & Evaluation \\
\hline Typhoon & ++ \\
\hline Pests and diseases & + \\
\hline Forest fire & +++ \\
\hline
\end{tabular}

\section{CONCLUSIONS AND DiscUSSIONS}

The cost comparison between of FSC and non-FSC plantations shows that though FSC plantations require more money and efforts in harvesting, the cost for transportation is reduced therefore, total income from FSC forest is higher, especially when plus with price premium that the certificate brings (about 25\% higher, [8]). It is clear that with FSC certification the value of Acacia plantation forest in Quang Tri province will increase compared to the non-certified forest. However, since currently the certification is subsidized and stumpage price is kept at higher than normal to foster the participation of local people the current price premium should be treated with caution. As for sustainable development, local people need to manage the certification by themselves which then, required them to have a good financial plan to cover the necessary costs. Membership fee is clearly a potential source in order to maintain the group. Further calculation need to be carried out in order to know how much membership fee can be collected in order to maintain the certification while do not affect to local people' revenue.

\section{REFERENCES}

[1] B. Cashore et al., "Confronting sustainability: forest certification in developing and transitioning countries," Report 8, 2006.

[2] FAO, "Asia-pacific forestry sector outlook study II," Working Paper Series, 2009.

[3] T. S. H. Pham, "An explorative study on functional upgrading and export development of Vietnam wood furniture producers," Depocen Working Paper Series, 2009.

[4] Ministry of Agriculture and Rural Development, Vietnam Forestry Development Strategy 2006-2020, Agriculture Publisher, 2007.

[5] Ministry of Agriculture and Rural Development, Vietnam Forestry Development Strategy 2006-2020, Agriculture Publisher, 2000.

[6] H. T. Thai, D. K. Lee, and S. Y. Woo, "Growth of several indigenous species in the degraded forest in the northern Vietnam," International Journal of the Physical Sciences, vol. 5, no. 17, pp. 2664-2671, 2010.

[7] S. McNamara, D. V. Tinh, P. D. Erskine, D. Lamb, D. Yates, and S Brown, "Rehabilitating degraded forest land in central Vietnam with mixed native species plantings," Forest Ecology and Management, vol. 233, pp. 358-365, 2006.

[8] H. T. N. Hoang, S. Hoshino, and S. Hashimoto, "Forest stewardship council certificate for a group of planters in Vietnam: SWOT analysis and implications," Journal of Forest Research, vol. 20, no. 1. 
Hai Thi Nguyen Hoang was born in May, 1984 in Vietnam. She is a third years' doctoral student at the Graduate School of Global Environmental Studies, Kyoto University, Japan. Her research and academic interests are in the field of forest management, where she focuses on community forest management and forest certification.

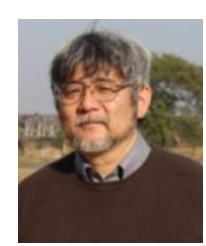

Satoshi Hoshino is a professor of the Laboratory of Sustainable Rural Development, Kyoto University. His interests lie on rural planning association, agriculture and rural engineering, regional agriculture and forestry.

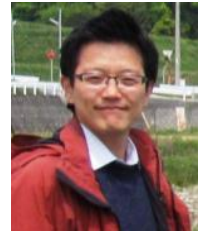

Shizuka Hashimoto is an associate professor of the Laboratory of Sustainable Rural Development, Kyoto University. His research interests include land use planning, land use and cover change, participatory planning and the management of ecosystem services. 